\title{
KKMT Joint Mobilization: Scientific Reconciliation of the Principles and Techniques
}

\author{
Chakshu Bansal Kathuria ${ }^{1 *}$, Kuki Bordoloï, Ankita Kashyap ${ }^{3}$, Mrityunjay Sharma ${ }^{4}$ and Jyoti Sharma ${ }^{5}$ \\ ${ }^{1}$ Physio Needs Academy, India \\ ${ }^{2}$ Guwahati Medical College, India
}

${ }^{3}$ Department of Medicine, Gajraraja Medical College, India

${ }^{4}$ Department of Respiratory Medicine, Banaras Hindu University, India

${ }^{5}$ MGH Medical College, India

Submission: January 18, 2018; Published: February 06, 2018

*Corresponding author: Chakshu Bansal Kathuria, Physio Needs Academy, New Delhi, India, Email: physioneedsacademy@gmail.com

Abstract

Manual Therapy is a growing domain in Physical Therapy with several schools of thoughts. Krishna's Kinetikinetic Manual Therapy® (KKMTß) is one of the newest schools of thought in manual therapy developed in the $21^{\text {st }}$ century. This article reconciles its principles and techniques with other researches.

Keywords: Manual therapy; Physical therapy; KKMT; Krishna's kinetikinetic manual therapy

\section{Introduction}

Krishna's Kinetikinetic Manual Therapy® (KKMT®) is the latest school of thought in manual therapy founded by Dr. Krishna N. Sharma, a Physiotherapist from India. KKMT® Joint Mobilization is a part of KKMT® as a whole [1].

\section{Principles}

The KKMT® joint mobilization techniques are based on the following principle [2]:

A. Proper arthrokinematic motion and homeostatic kinetic forces are essential for proper and smooth osteokinematic motion.

B. Homeostatic kinetics of the joint is important to maintain static and dynamic alignment of a joint.

C. Limitation or restrictions in the arthrokinematic motion can be restored by facilitating homeostatic kinetics of the intrinsic and extrinsic factors.

\section{Guidelines for Therapists} [3]:

Dr. Sharma gave the following guidelines to the therapists

A. Use biopsychosocial model for evaluation and treatment.
B. Structural asymmetry should not be an issue of special concern until it falls in the category of abnormal. Asymmetry is very normal in the human body.

C. Evaluate functional motions, wherever possible.

D. Don't use nocebic terminologies while discussing with patients/ family.

E. Avoid catastrophobia. Make sure that the patient understands the condition rather than being scared of.

\section{Techniques and Application}

The KKMT® Joint Mobilization is applied after muscle and joint conditioning. There are three techniques which are combined with passive movement, active movement, reciprocal inhibition, autogenic inhibition and resistance training [3]:

A. Joint gapping: In this technique, the therapist uses his fist as a fulcrum near the joint line and provides joint distraction by applying force on the distal end of the distal segment.

B. Movement/ Rolling facilitation: In this technique, the therapist counter-glides the joint to facilitate rolling.

C. 3D Gliding: In this technique, the therapist applies three dimensional glides for three dimensional functional motions. 


\section{Scientific Reconciliation of the components of KKMT $^{\circledast}$}

a. Biopsychosocial Approach: The biopsychosocial approach has been found effective and is recommended by various researchers [4-6].

b. Counselling: The therapist briefs the patient about his/ her condition and treatment in simplified layman terms without using medical jargons or terms. The therapist also educates the patient about the psychosocial model of pain and restriction. The effects of counselling on of changing patient's behaviour, perception of pain and catastrophobia desensitization are supported by various researchers [7-9].

c. Motion facilitation techniques: Thought there is not work done on using counter-glide to facilitate natural functional rolling, the other effects of exposure to movement like cortical reorganization, catastrophobia desensitization have been proved to be effective in pain [10-12].

d. 3D Glides: These complex passive glides are biomechanically designed to facilitate the natural glides during functional motions and provide pain free course of arthrokinematic motion. They may be applied while the joint is in resting position and can be followed by passive and active osteokinematic motion. The glides are found effective in increasing range of motion and decreasing pain $[13,14]$.

e. Resistive motions: The patient is asked to do resistive training with the glides and facilitation to changes muscle memory using the neuroplasticity and helps the muscles relearn the amount and direction of homeostatic forces. The muscle memory and neuroplasticity are found effective in pain management [15-18].

f. Autogenic/ reciprocal inhibition: The 3D glides and facilitation patterns are combined with autogenic/ reciprocal inhibition too. The effectiveness of these inhibition techniques in gaining range of motion by relaxing the antagonists are proved by various researchers [19-21].

\section{Conclusion}

The principles and techniques of KKMT® joint mobilization techniques are found to be effective after scientifically reconciliation. We need more reconciliation and hence would conclude with the Latin phrasenanos gigantum humeris insidentes or as said by Isaac Newton in 1675: "If I have seen further it is by standing on the shoulders of Giants.

\section{References}

1. Sharma KN (2016) KKMT Mobilization Peripheral Joints. J Nov Physiother 6(5): 62.

2. Sharma KN (2016) KKMT® Mobilization-The Upper Extremities. Mau: Academy of KKMT.
3. Sharma KN, Kathuria CB (2017) Practical guide on Krishna's Kinetikinetic Manual Therapy- Peripheral Joint Mobilization. Academy of KKMT, India.

4. Baert IA, Meeus M, Mahmoudian A, Luyten FP, Nijs J, et al. (2017) Do Psychosocial Factors Predict Muscle Strength, Pain, or Physical Performance in Patients With Knee Osteoarthritis? J Clin Rheumatol 23(6): 308-316.

5. Gatchel RJ, Peng YB, Peters ML, Fuchs PN, Turk DC (2007) The biopsychosocial approach to chronic pain: scientific advances and future directions. Psychol Bull 133(4): 581-624.

6. Nielson WR, Weir R (2001) Biopsychosocial approaches to the treatment of chronic pain. The Clin J Pain 17(4 Suppl): S114-S127.

7. Blasini M, Corsi N, Klinger R, Colloca L (2017) Nocebo and pain: an overview of the psychoneurobiological mechanisms. Pain Rep 2(2): e585.

8. Bąbel P, Bajcar EA, Adamczyk W, Kicman P, Lisińska N, et al. (2017) Classical conditioning without verbal suggestions elicits placebo analgesia and nocebo hyperalgesia. PloS one 12(7): e0181856.

9. Dogancil B, Breimhorstl M, Hondrichl M, Rodriguez Raeckel R, Mayl A, et al. (2011) Expectations modulate long-term heat pain habituation. Eur J Pain 15(4): 384-388.

10. Rennefeld C, Wiech K, Schoell ED, Lorenz J, Bingel U (2010) Habituation to pain: further support for a central component. PAIN® 148(3): 503508.

11. Bingel U, Schoell E, Herken W, Büchel C, May A (2007) Habituation to painful stimulation involves the antinociceptive system. Pain 131(1-2): 21-30.

12. Milne RJ, Kay NE, Irwin RJ (1991) Habituation to repeated painful and non-painful cutaneous stimuli: a quantitative psychophysical study. Exp Brain Res 87(2): 438-444.

13. Johnson AJ, Godges JJ, Zimmerman GJ, Ounanian LL (2007) The effect of anterior versus posterior glide joint mobilization on external rotation range of motion in patients with shoulder adhesive capsulitis. J Orthop Sports Phys Ther 37(3): 88-99.

14. Moss P, Sluka K, Wright A (2007) The initial effects of knee joint mobilization on osteoarthritic hyperalgesia. Man Ther 12(2): 109-118.

15. Abrahamsson S (2017) Neuroplasticity Induced by Exercise, University in Skövde, Sweden, pp. 1-56.

16. Gourgouvelis J, Yielder P, Murphy B (2017) Exercise promotes neuroplasticity in both healthy and depressed brains: An fMRI pilot study. Neural Plasticity 2017(2017): 8305287.

17. Marzouk S (2017) S182 Introduction to neuroplasticity and its application in neurorehabilitation. Clinical Neurophysiology 128(9): e237.

18. Pinzon D, Vega R, Sanchez YP, Zheng B (2016) Skill learning from kinesthetic feedback. The American Journal of Surgery 214(4): 721725

19. Knierim J (2018) Neuroscience Online, Chapter 2: Spinal Reflexes and Descending Motor Pathways, USA.

20. Sharman MJ, Cresswell AG, RiekS (2006) Proprioceptive neuromuscular facilitation stretching: mechanisms and clinical implications. Sports Medicine 36(11): 929-939.

21. Crone C (1993) Reciprocal inhibition in man. Dan Med Bull 40(5): 571581 


Your next submission with Juniper Publishers
will reach you the below assets
- Quality Editorial service
- Swift Peer Review
- Reprints availability
- E-prints Service
- Manuscript Podcast for convenient understanding
- Global attainment for your research
- Manuscript accessibility in different formats
( Pdf, E-pub, Full Text, Audio)
- Unceasing customer service
Track the below URL for one-step submission
https://juniperpublishers.com/online-submission.php

